\title{
Formulasi dan Uji Aktivitas Krim Pengkelat Merkuri Berbahan Dasar Ekstrak Etanol Alga Coklat (Sargassum sp.)
}

\author{
Inda Putrinesia ${ }^{a}$, Yoga Pratama Lumban Tobing ${ }^{\text {, }}$ Nurul Asikin ${ }^{\text {a }}$, Winda Rahmalia ${ }^{a}$ \\ ${ }^{a}$ Jurusan Kimia, Fakultas Matematika dan Ilmu Pengetahuan Alam, Universitas Tanjungpura \\ ${ }^{b}$ Program Studi Profesi Apoteker, Fakultas Kedokteran, Universitas Tanjungpura \\ Jl. Prof.Dr.H. Hadari Nawawi, Pontianak Tenggara, Pontianak, 78115 \\ * Corresponding author \\ E-mail: indaputrinesia0908@student.untan.ac.id
}

DOI: 10.20961/alchemy.14.1.12242.152-163

Received 16 August 2017, Accepted 11 December 2017, Published 1 March 2018

\begin{abstract}
ABSTRAK
Telah dilakukan penelitian tentang formulasi dan uji aktivitas krim pengkelat merkuri berbahan dasar ekstrak etanol alga coklat (Sargassum sp.). Krim diformulasikan dengan beberapa bahan seperti vaselin, gliserol, asam askorbat, karbomer, setil alkohol, dan $\mathrm{NaOH}$. Parameter yang dievaluasi diantaranya organoleptik krim, homogenitas, $\mathrm{pH}$, daya sebar, tipe krim, iritasi kulit dan daya tercuci krim. Aktivitas pengkelatan diamati dengan menganalisis kandungan merkuri pada kulit tikus yang sebelumnya diberikan krim bermerkuri dibandingkan dengan kulit tikus yang telah dioleskan krim pengkelat merkuri berbahan dasar ekstrak etanol alga coklat. Spektrum Fourier Transform Infrared Spectroscopy (FT-IR) menunjukkan bahwa ekstrak etanol alga coklat diindikasikan mengandung glutation. Berdasarkan parameter evaluasi krim, formulasi terbaik adalah krim dengan komposisi ekstrak alga coklat sebanyak $0,035 \% \mathrm{w} / \mathrm{v}$ terhadap volume krim, yang ditandai dengan krim yang berbentuk gel kental dan tidak berbau serta memiliki tekstur seperti krim wajah pada umumnya, yaitu lembut dan sedikit berminyak. Krim bersifat homogen dan stabil hingga hari ke 21 percobaan dengan $\mathrm{pH}=5$. Krim juga tidak menimbulkan iritasi dan dapat tercuci habis tanpa bekas. Hasil analisis AAS membuktikan bahwa penggunaan krim pengkelat merkuri berbahan dasar esktrak etanol alga coklat selama kurang dari 2 minggu dengan dosis pemberian 1 kali sehari mampu menyerap merkuri pada tikus dengan aktivitas penyerapan sebesar $50 \%$.
\end{abstract}

Kata kunci: alga coklat, glutation, kelat, krim, merkuri

\section{ABSTRACT}

Formulation and Activity Test of Mercury Chelator Cream of Ethanol Extract of Brown Algae (Sargassum Sp.). Research on the study of formulation an activity test of mercury chelator cream from ethanol extract has successfully done. The cream was formulated with ingredients such as vaseline, glycerol, ascorbic acid, carbomer, cetyl alcohol, and sodium hydroxide. Parameters were evaluated against organoleptic, homogenity, $\mathrm{pH}$, dispersion type of cream, skin irritation test, and washing test. The mercury chelating activity was observed by analyzing mercury concentration in mercury induced mouse skin. The FTIR spectrum showed that ethanol extract of brown algae was dominated by glutathione functional group. The best cream formulation was composed by $0,035 \%(\mathrm{w} / \mathrm{v})$ brown algae, formed as a creamy gel that was thick and odorless and had a texture like soft facial cream in general with slightly oily.The cream was homogeneous and stable until the $21^{\text {st }}$ day of the experiment with $\mathrm{pH}=5$. The cream produced no skin irritation and could be washed out without a trace. The results of AAS analysis proved that the use of brown 
algae ethanol extract-based mercury chelating cream for less than 2 weeks with a dose of 1 time a day could absorb mercury in mouse skin with absorption activity of $50 \%$.

Keywords: brown algae, glutatione, chelate, cream, mercury

\section{PENDAHULUAN}

Merkuri dan garam merkuri dalam bentuk klorida dan oksida merupakan bahan kimia berbahaya yang sering ditemukan dalam kosmetik ilegal terutama dalam sabun dan krim pemuth (whitening skin). Senyawa merkuri tersebut digunakan sebagai pengawet atau antijamur (Chan, 2011; Mallkuci and Lazo, 2014). Bila merkuri terpapar pada wajah atau bagian kulit lainnya, merkuri akan mengendap dalam jangka waktu tertentu sebelum masuk kedalam darah dan diteruskan ke organ lainnya (Silberg et al., 2013). Merkuri dapat menyebabkan ruam kulit, ruam kulit, kerusakan jaringan parut, penurunan resistensi kulit terhadap infeksi bakteri dan jamur hingga kerusakan ginjal secara permanen (WHO, 2014; Park and Zheng, 2012).

Penanganan umum yang diberikan pada kulit pasca terpapar merkuri yaitu dengan menggunakan senyawa pengkelat seperti penisilamin (Rafati et al., 2014). Akan tetapi terapi ini menimbulkan beberapa efek samping cukup berbahaya. Penelitian Ishak and Abbas (2013) menunjukkan bahwa 7\% pasien yang menerima terapi penisilamin selama 6 bulan mengalami pemfigus serta mengalami keterbatasan lisan, penyakit mulut dan kulit pada $11 \%$ kasus lainnya. Oleh sebab itu, salah satu alternatif dalam penanganan keracunan merkuri yang aman seperti dengan menggunakan glutation yang juga dapat berperan sebagai agen pengkelat ion logam seperti merkuri (Patra et al., 2007).

Glutation (Gambar 1) merupakan golongan senyawa sulfihidril (-SH) atau thiol yang berperan pada detoksifikasi senyawa elektrofilik xenobiotik. Semua senyawa thiol sangat reaktif membentuk kelat dengan merkuri. Kelat merupakan senyawa yang dihasilkan oleh kombinasi senyawa yang mengandung gugus elektron donor yang dapat membentuk suatu struktur cicin. Hasil kelat merkuri-glutation dilaporkan oleh Patra et al. (2007) dapat mempercepat onset dari sekresi urin oleh ginjal sebagai asam merkapturat.

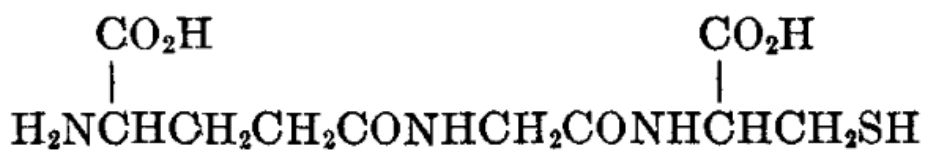

Gambar 1. Struktur kimia glutation (Ben and Nicolet, 1930) 
Salah satu sumber glutation yang aman dan memiliki banyak manfaat kesehatan adalah alga coklat (Sargassum sp.). Spesies alga coklat banyak ditemukan di wilayah perairan Indonesia, termasuk Pulau Lemukutan, Kalimantan Barat (Anggadiredja et al., 2011). Alga coklat secara farmakologi telah digunakan sebagai antibakteri, anti inflamasi dan antitumor karena mengandung antioksidan yang tinggi. Glutation larut baik dalam etanol (Xiong et al., 2008; Piao et al., 2011). Oleh karena itu, artikel ini melaporkan studi mengenai formulasi krim berbahan dasar ekstrak etanol alga coklat sebagai krim pengkelat merkuri. Pengujian secara topikal diberikan pada tikus jalur wistar sebagai hewan uji yang sebelumnya telah terpapar merkuri. Analisis kadar merkuri pada jaringan kulit tikus pasca pemberian krim alga coklat dilakukan menggunakan Spektrofotometri Serapan Atom (SAA).

\section{METODE PENELITIAN}

\section{Preparasi Ekstrak Etanol Alga Coklat}

Sampel alga coklat diambil di Pulau Lemukutan, Kabupaten Bengkayang, Provinsi Kalimantan Barat. Sampel dikeringkan di bawah sinar matahari selama 7 hari hingga warna berubah menjadi kehitaman, dan dihaluskan menggunakan blender. Simplisia kemudian dimaserasi menggunakan pelarut etanol absolut (EMPARTA ACS) selama $3 \mathrm{x}$ 24 jam, dievaporasi dan dikeringkan dalam oven pada suhu $70{ }^{\circ} \mathrm{C}$ selama 3 hari hingga diperoleh ekstrak kering (Armando, 2009). Esktrak etanol alga coklat yang dihasilkan dianalisa menggunakan FTIR.

\section{Formulasi Krim Esktrak Etanol Alga Coklat}

Formulasi krim dilakukan dengan memodifikasi metode Ansel (2005). Basis air dibuat dengan menambahkan sebanyak 0,5 g karbomer ditambahkan ke dalam $20 \mathrm{~mL}$ akuades panas, diaduk hingga homogen dan terbentuk muscilago, selanjutnya ditambahkan $3 \mathrm{~mL}$ gliserol. Karbomer digunakan sebagai bahan pembentuk krim yang dapat mengentalkan dan menahan hilangnya zat aktif atau fraksi dari kulit. Basis minyak dibuat dengan mencampurkan 0,18 $\mathrm{g}$ asam askorbat, $1 \mathrm{~g}$ setil alkohol, dan $5 \mathrm{~g}$ vaselin alba (Clorogreen) dalam cawan uap pada suhu $108{ }^{\circ} \mathrm{C}$ hingga melarut dan homogen. Dicampurkan secara perlahan basis minyak ke dalam basis air dan diaduk homogen hingga terbentuk krim, dan ditambahkan ekstrak etanol alga coklat dengan konsentrasi masingmasing 0,$035 ; 0,07$ dan $0,105 \%$ w/v terhadap volume krim dan diaduk homogen. Krim 
selanjutnya disebut dengan krim pengkelat KP I, KP II, dan KP III untuk masing-masing krim yang mengandung 0,$035 ; 0,07$ dan $0,105 \%$ w/v.

\section{Evaluasi Krim Ekstrak Etanol Alga Coklat}

Evaluasi Organoleptik Krim (SNI 01-2346-2006)

Uji organoleptik meliputi bentuk, warna, bau dan tekstur krim yang dihasilakn. Responden yang digunakan sebanyak 10 orang (5 laki-laki dan 5 perempuan) dengan usia 20-22 tahun.

Evaluasi Homogenitas Krim (Departemen Kesehatan RI, 1985)

Sebanyak 0,1 g krim dioleskan secara merata dan tipis pada cawan petri. Evaluasi dilakukan pada hari ke-0, 7, 14 dan 21. Homogenitas krim ditandai dengan tidak terlihatnya bintik-bintik maupun serbuk serta gelembung pada hasil olesan.

Evaluasi pH Krim (Departemen Kesehatan RI, 1985)

Sebanyak 1 g krim dilarutkan dan diencerkan dengan akuades hingga $10 \mathrm{~mL}$, diukur $\mathrm{pH}$ menggunakan indikator universal.

Evaluasi Daya Sebar (Voigt, 1994)

Sebanyak 0,5 g krim diletakkan diatas kaca transparan yang dilapisi dengan kertas grafik, dibiarkan selama 15 detik dan dihitung luas daerah yang diberikan oleh basis, kemudian ditutup dengan plastik transparan, dan diberi beban (1, 3, 5 dan 7 g), dibiarkan selama 60 detik. Dihitung pertambahan luas yang diberikan oleh basis.

Evaluasi Tipe Krim (SNI 16-4399-1996)

Ditambahkan 2 tetes metilen biru ke dalam 0,1 g krim, kemudian diamati penyebaran warna dari metilen biru dibawah mikroskop.

Evaluasi Iritasi Kulit (Wathoni et al., 2009)

Sejumlah krim dioleskan pada kulit manusia dan diamati selama 24 jam.

Evaluasi Daya Tercuci Krim (Scoville and Jenkins, 1957)

Sebanyak 1 g krim dioleskan pada telapak tangan, selanjutnya dicuci dengan sejumlah air sambil dibilas secara periodik.

\section{Preparasi dan Analisis Krim Bermerkuri}

Krim bermerkuri diperoleh di pasar tradisional di sekitar Kota Pontianak. Krim tersebut dianalisa menggunakan SSA.

\section{Preparasi Hewan Uji}

Hewan uji yang digunakan dalam penelitian yaitu tikus putih (Rattus novergicus) galur wistar yang diperoleh dari peternak hewan bersertifikat di Kota Pontianak. Hewan uji 
berusia 6 minggu. Hewan uji diaklimatisasi terlebih dahulu selama 7 hari di lingkungan laboratorium untuk menyesuaikan diri dengan lingkungan baru, diberi makan pakan standar dan minum ad libitum.

\section{Proses Perlakuan Hewan Uji}

Hewan uji dicukur bulu punggung seluas 5 x $2 \mathrm{~cm}$ dan dibersihkan menggunakan alcohol swab. Hewan uji kemudian dibagi menjadi 3 kelompok yaitu (1) kelompok kontrol positif yaitu tidak diinduksi merkuri, (2) kelompok kontrol negatif yang diinduksi merkuri selama 14 hari, dan (3) kelompok perlakuan yang diinduksi merkuri selama 14 hari dan selanjutnya diberikan krim alga coklat selama 3 hari.

Tikus kelompok 2 dan 3 diinduksi krim bermerkuri sehari sekali dengan mengoleskan secara merata sebanyak 0,2 g krim pada bagian punggung setiap kali perlakuan. Kemudian kelompok 1 dibiarkan tanpa diberi perlakukan apapun, sedangkan kelompok 3 pada hari ke-15, setelah tikus terinduksi merkuri diberikan sebanyak 0,2 $\mathrm{g}$ krim pengkelat alga coklat I.

\section{Analisis Kadar Merkuri (Hg) Hewan Uji}

Analisis kadar merkuri ( $\mathrm{Hg})$ hewan uji dilakukan dengan mengambil jaringan kulit hewan uji seluas $5 \mathrm{~cm} \times 2 \mathrm{~cm}$. Sejumlah jaringan kulit yang diperoleh kemudian dianalisa menggunakan Spektrofotemetri Serapan Atom (SSA). Analisis SSA dilakukan di Lab Kesehatan Pontianak. Analisis dilakukan sebanyak dua kali (duplo).

\section{PEMBAHASAN}

\section{Karakteristik Ekstrak Etanol Alga Coklat (Sargassum sp.)}

Spektra FT-IR pada Gambar 2 menunjukkan bahwa ekstrak etanol alga coklat diindikasikan mengandung glutation dengan adanya serapan tajam pada beberapa bilangan gelombang yang disajikan pada Tabel 1. Adanya puncak serapan N-H, C-N dan C-H memperkuat kemungkinan kandungan glutation dalam ekstrak etanol alga coklat.

\section{Evaluasi Krim Alga Coklat}

Tujuan utama dari formulasi ekstrak etanol alga coklat kedalam bentuk sediaan krim adalah untuk meningkatkan efektivitas ekstrak tersebut dalam mengkelat senyawa merkuri pada lapisan kulit. Hal tersebut disebabkan krim dapat menghantarkan sediaan obat lebih cepat pada lapisan kulit dibandingkan dengan sediaan topikal lainnya. Selain itu, krim memiliki tekstur yang lembut, tidak lengket, dan mudah mengering sehingga memudahkan saat dicuci (Voight, 1994). Evaluasi krim yang dilakukan selanjutnya 
bertujuan untuk menentukan formulasi krim yang optimum antar ketiga sediaan (KP I, KP II, dan KP III). Hasil uji organoleptik krim disajikan pada Tabel 2.

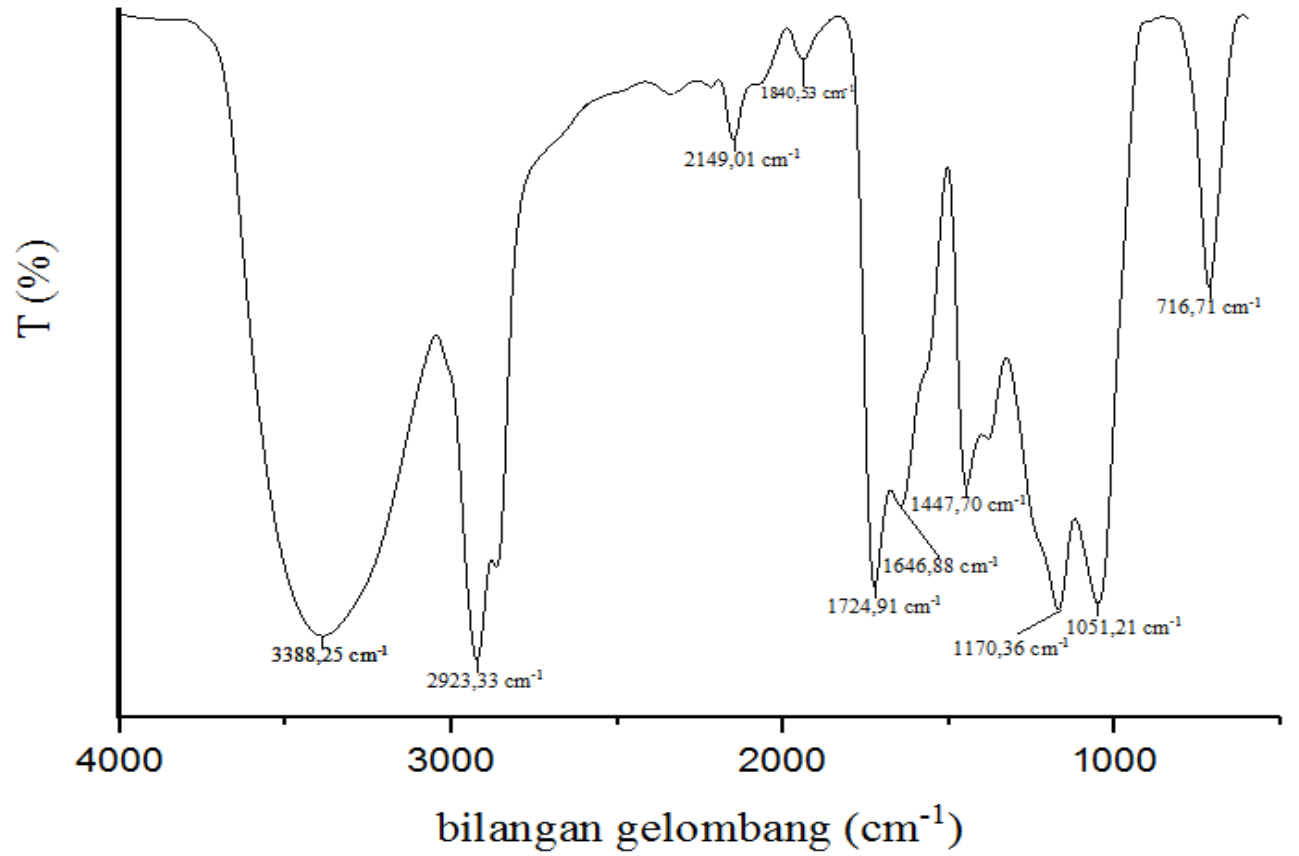

Gambar 2. Hasil Analisis FT-IR Ekstrak Etanol Alga Coklat

Tabel 1. Puncak Serapan FTIR dari Ekstrak Etanol Alga Coklat* dan Glutation ${ }^{* * *}$

\begin{tabular}{ccc}
\hline Ekstrak Etanol Alga* Coklat $\left(\mathbf{c m}^{-\mathbf{1}}\right)$ & Glutation** $\left(\mathbf{c m}^{\mathbf{- 1}}\right)$ & Interpretasi \\
\hline 3388 & 3348 & NH streching \\
2923 & 2529 & SH streching \\
2149 & 2125 & SH streching \\
1840 & 1713 & C=O streching \\
1724 & 1713 & Amida I \\
1646 & 1662 & Amida I \\
1447 & 1537 & Amida I \\
1170 & 1235 & Amida III \\
1051 & 1035 & NH \\
717,7 & 716,0 & C-H rocking \\
\hline
\end{tabular}

* dilakukan oleh peneliti

** dilakukan oleh Picquart et al. (1999)

Tabel 2. Hasil Uji Organoleptik Krim

\begin{tabular}{|c|c|c|c|c|}
\hline Krim & Bentuk & Warna & Bau & Tekstur \\
\hline Kontrol & Kental & Putih susu & Tidak berbau & $\begin{array}{l}\text { Lembut dan } \\
\text { berminyak }\end{array}$ \\
\hline KP I & Kental & Hijau muda & Tidak berbau & $\begin{array}{l}\text { Lembut dan } \\
\text { berminyak }\end{array}$ \\
\hline KP II & Agak cair & $\begin{array}{l}\text { Hijau keputihan dengan bintik } \\
\text { hijau tua }\end{array}$ & Agak amis & Lembut berair \\
\hline $\mathbf{K P}$ & Kental & $\begin{array}{c}\text { Hijau tua dengan bintik hijau } \\
\text { tua }\end{array}$ & Amis & $\begin{array}{l}\text { Lembut dan } \\
\text { berminyak }\end{array}$ \\
\hline
\end{tabular}


Tabel 2 menunjukkan bahwa KP I dan KP III memiliki kemiripan bentuk dengan krim kontrol. Dari segi warna, KP I memiliki warna yang lebih stabil yang ditandai dengan tidak ditemukannya bintik-bintik bewarna hijau. Bintik bewarna pada krim menunjukkan bahwa krim memiliki homogenitas yang buruk. Ditinjau dari aroma, KP I tidak berbau dibandingkan dengan KP II dan KP III. Hal tersebut disebabkan oleh bau khas alga coklat yang amis seiring dengan peningkatan dosis. Namun, dalam implementasi lebih lanjut, bau amis dapat ditutupi dengan penambahan senyawa pembau seperti rosea aromatica. Berdasarkan parameter tekstur, hanya KP II yang berair yang diduga terjadi akibat basis air dan basis minyak tidak bercampur baik. Krim yang berair lebih mudah berjamur sehingga memiliki stablilitas yang jelek. Berdasarkan evaluasi organoleptik ini, KP I merupakan krim yang optimum dibanding dengan KP II dan KP III.

Uji homogenitas dilakukan selama 21 hari untuk melihat apakah krim mengalami degradasi fisik setelah krim disimpan selama 3 minggu. Degradasi fisik ditandai dengan perubahan wujud krim dari kental menjadi cair, tanpa bintik menjadi berbintik, serta dari tidak terdapat gelembung busa menjadi dijumpainya gelembung busa. Selain itu, degradasi fisik menandai bahwa krim tidak tahan dalam proses penyimpanan. Hasil uji homogenitas dapat dilihat pada Gambar 3 dan Tabel 3.
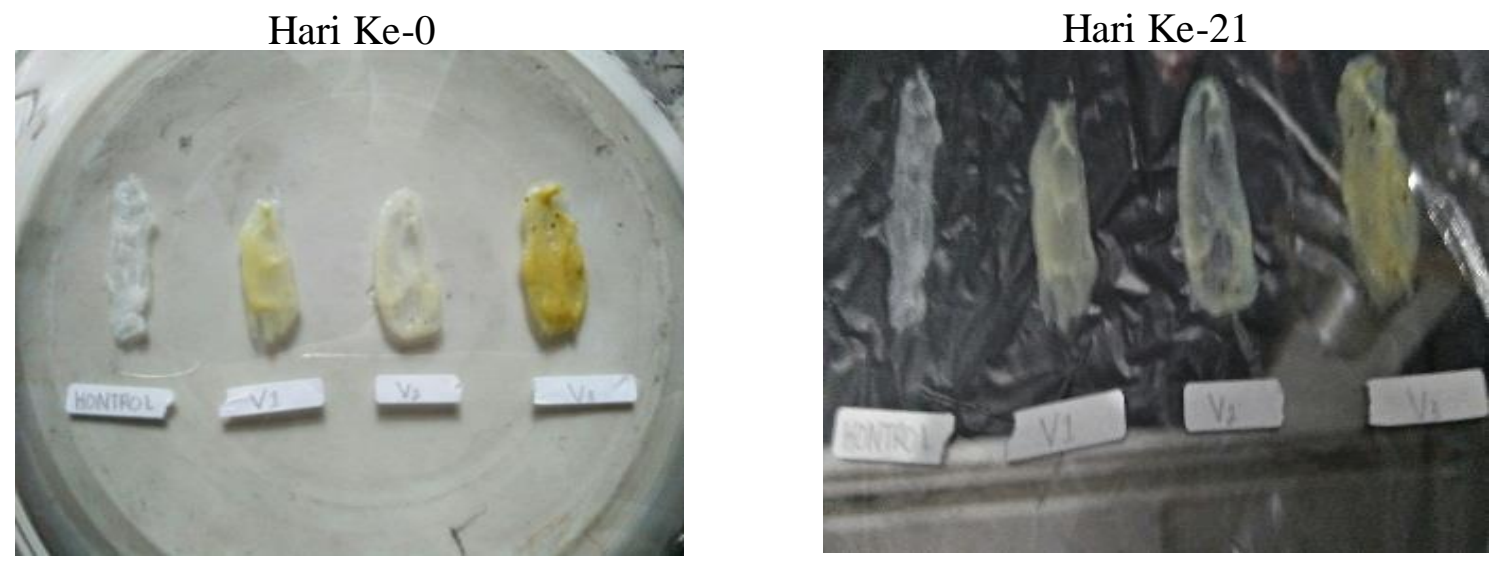

Gambar 3. Hasil Uji Homogenitas Krim Pasca Produksi Hari ke-0 dan hari ke-21

Tabel 3. Hasil Uji Homogenitas Krim

\begin{tabular}{|c|c|c|c|c|}
\hline Tipe Krim & Hari ke-0 & Hari ke-7 & Hari ke-14 & Hari ke-21 \\
\hline Kontrol & $\begin{array}{l}\text { Halus tak } \\
\text { berbintik }\end{array}$ & $\begin{array}{l}\text { Halus kering } \\
\text { seperti lilin }\end{array}$ & Halus kering & Halus kering \\
\hline KP I & $\begin{array}{l}\text { Halus tak } \\
\text { berbintik }\end{array}$ & $\begin{array}{l}\text { Halus tanpa } \\
\text { bintik }\end{array}$ & $\begin{array}{l}\text { Halus tanpa } \\
\text { bintik }\end{array}$ & $\begin{array}{l}\text { Halus tanpa } \\
\text { bintik }\end{array}$ \\
\hline $\mathbf{K P}$ & $\begin{array}{l}\text { Berbintik hijau } \\
\text { dan bening }\end{array}$ & Berbintik hijau & $\begin{array}{l}\text { Kasar bintik } \\
\text { hijau }\end{array}$ & $\begin{array}{c}\text { Berbutir bintik } \\
\text { hijau }\end{array}$ \\
\hline $\mathbf{K P}$ & $\begin{array}{c}\text { Sedikit berbintik } \\
\text { hijau }\end{array}$ & $\begin{array}{c}\text { Sedikit } \\
\text { berbintik hijau }\end{array}$ & $\begin{array}{c}\text { Sediit } \\
\text { berbintik hijau }\end{array}$ & $\begin{array}{c}\text { Sedikit } \\
\text { berbintik hijau }\end{array}$ \\
\hline
\end{tabular}


Hasil uji homogenitas menunjukkan bahwa KP II dan KP III tidak memenuhi kriteria. Hal tersebut disebabkan karena terdapat bintik pada krim yang diporduksi baik pada hari ke-0 hingga hari ke-21. Sedangkan KP I pada hari ke-0 hingga hari ke-21 tidak dijumpai adanya tanda-tanda ketidakcampuran. Selain itu, KP I merupakan krim yang mendekati dengan krim kontrol. Oleh sebab itu, KP I merupakan krim yang paling stabil secara uji homogenitas dengan variasi hari.

Tabel 4 menunjukkan bahwa semua krim yang dilakukan uji pH memenuhi kriteria. Parameter pengujian $\mathrm{pH}$ sediaan yaitu sesuai dengan $\mathrm{pH}$ kulit yaitu antara 4,2-5,6. Hal tersebut disebabkan karena kulit terutama kulit wajah sangat sensitif pada perubahan $\mathrm{pH}$ yang terlalu ekstrim, oleh sebab itu kesesuaian $\mathrm{pH}$ merupakan hal yang mutlak. Selain itu, ketidaksesuaian $\mathrm{pH}$ krim dapat menyebabkan dampak negatif pada kesehatan kulit seperti munculnya bercak hitam, jerawat, hingga mengakibatkan kulit menjadi kusam (Rowe et al., 2009).

Tabel 4. Hasil Uji pH, Tipe Krim dan Iritasi Kulit

\begin{tabular}{ccccc}
\hline \multirow{2}{*}{ Parameter } & Kontrol & KP I & KP II & KP III \\
\cline { 5 - 6 } $\mathrm{pH}$ & 5 & 5 & 5 & 5 \\
\cline { 5 - 6 } Tipe krim & $\mathrm{M} / \mathrm{A}$ & $\mathrm{M} / \mathrm{A}$ & $\mathrm{A} / \mathrm{M}$ & $\mathrm{A} / \mathrm{M}$ \\
\cline { 1 - 2 } Uji iritasi kulit & $\begin{array}{c}\text { Tidak terjadi } \\
\text { iritasi }\end{array}$ & $\begin{array}{c}\text { Tidak terjadi } \\
\text { iritasi }\end{array}$ & $\begin{array}{c}\text { Tidak terjadi } \\
\text { iritasi }\end{array}$ & $\begin{array}{c}\text { Tidak terjadi } \\
\text { iritasi }\end{array}$ \\
\hline
\end{tabular}

Uji tipe krim menunjukkan bahwa krim kontrol dan KP I merupakan krim tipe minyak dalam air (M/A), sedangkan KP II dan KP III merupakan krim dengan tipe air dan minyak (A/M). Perubahan bentuk tipe emulsi krim yang diproduksi disebabkan oleh penambahan ekstrak etanol alga coklat. Semakin tinggi konsentrasi etanol alga coklat yang ditambahkan maka akan mengakibatkan krim semakin berminyak. Hal tersebut disebabkan karena ekstrak etanol alga coklat merupakan ekstrak yang memiliki kadar minyak tinggi.

Krim tipe M/A lebih banyak digunakan dalam sediaan kosmetik dikarenakan tipe emulsi M/A lebih mudah untuk dibersihkan (Syamsuni, 2006). Selain itu, krim tipe M/A memiliki pelepasan obat yang baik karena jika krim kontak dengan kulit maka akan terjadi penguapan dan peningkatan konsentrasi dari suatu obat yang larut dalam air sehingga mempercepat penyerapan masuk ke dalam jaringan kulit (Aulton, 2003). Dalam hal ini, krim ekstrak etanol alga coklat diharapkan dapat terpenetrasi dengan cepat menuju lapisan kulit untuk mengkelat senyawa merkuri. 
Uji iritasi kulit menunjukkan tidak terdapatnya iritasi yang ditimbulkan ketika kontak langsung dengan kulit. Hal tersebut mengindikasikan bahwa penggunaan krim aman digunakan pada seluruh tipe kulit manusia. Sedangkan tipe tercuci krim menunjukkan bahwa KP I tidak meninggalkan bekas jika dibilas menggunakan air mengalir, sedangkan KP II masih meninggalkan bekas berupa butiran dan bau. KP III tidak meninggalkan butiran namun meninggalkan bau amis yang menyengat. Krim yang tidak meninggalkan bekas dengan air sangat aman digunakan kepada kulit karena jika suatu ketika kulit mengalami reaksi alergi maka krim dapat langsung dibilas. Selain itu, tingkat penerimaan konsumen lebih baik kepada krim yang dapat mudah hilang dengan air namun tidak mudah hilang oleh minyak.

Berdasarkan hasil evaluasi meliputi organoleptik, homogenitas, $\mathrm{pH}$, tipe emulsi, iritasi kulit, dan daya tersebar menunjukkan bahwa KP I merupakan krim yang paling baik dibandingkan dengan KP II dan KP III. Oleh sebab itu KP I selanjutnya digunakan untuk uji pre-klinik menggunakan sampel tikus sebagai krim pengkelat merkuri.

\section{Analisis Kadar Merkuri (Hg) Hewan Uji}

Kemampuan KP I dalam mengkelat merkuri dipelajari hanya dengan membandingkan kandungan merkuri yang ada dalam jaringan kulit tikus sebelum dan sesudah diberi KP I. Namun demikian, mengacu pada penelitian Mah and Jalilehvand (2010), interaksi yang terjadi antara logam merkuri dengan glutation adalah interaksi pengkelatan.

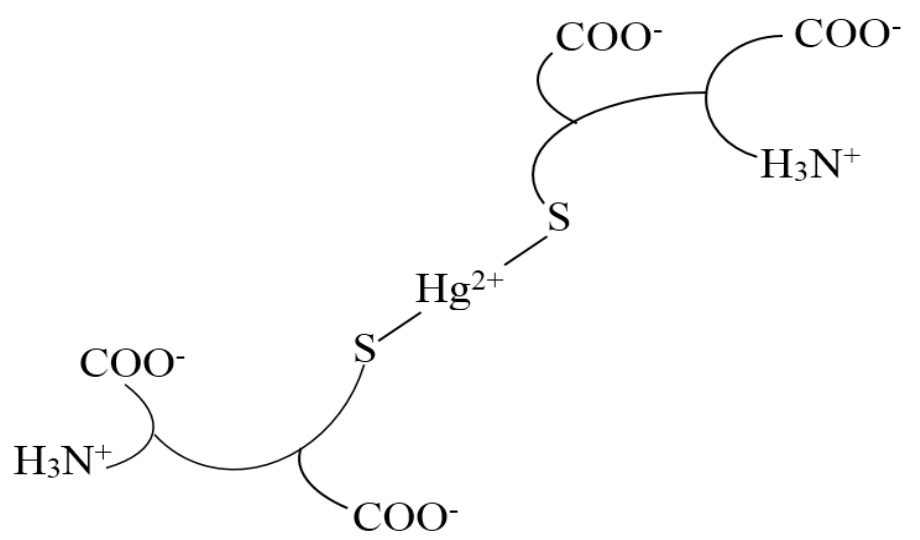

Gambar 4. Struktur yang dimungkinkan untuk merkuri(II)-glutation pada $\mathrm{pH} 7$ (Mah and Jalilehvand, 2010)

Hasil analisis merkuri dengan AAS terhadap jaringan kulit tikus disajikan pada Tabel 5. Tabel 5 menunjukkan bahwa setelah pemberian krim bermerkuri, terdapat kadar merkuri pada jaringan kulit tikus, yaitu 10 hingga 15 kali tinggi dibandingkan dengan kontrol. Setelah pemberian KP I selama 3 hari (dengan dosis 0,2 g per hari) pada hewan uji 
kelompok III, analisis AAS menunjukkan bahwa terjadi penurunan kadar merkuri didalam jaringan kulit tikus menjadi $\leq 0,0012$ dan $\leq 0,0013$. Hal tersebut menunjukkan bahwa pemberian KP I pada tikus terinduksi merkuri dapat menurunkan kadar merkuri pada jaringan kulit tikus sekitar 50\%. Dengan kata lain, persen penyerapan merkuri oleh KP I adalah $50 \%$.

Tabel 5. Hasil Analisa Merkuri Menggunakan Spektrofotometri Serapan Atom (SSA)

\begin{tabular}{lcr}
\hline No. & Kode & Hasil Uji Kadar Hg $(\mathbf{m g} / \mathbf{L})$ \\
\hline 1. & Kontrol 1 & $\leq 0,0002$ \\
2. & Kontrol 2 & $\leq 0,0002$ \\
3. & Krim Merkuri 1 & 0,0020 \\
4. & Krim Merkuri 2 & 0,0027 \\
5. & KP I 1 & $\leq 0,0012$ \\
6. & KP I 2 & $\leq 0,0013$ \\
\hline
\end{tabular}

\section{KESIMPULAN}

Formulasi optimum yang didapat adalah dengan penambahan sebanyak 0,035\% terdahap volume krim (w/v). Pemberian krim pengkelat merkuri berbahan dasar ekstrak etanol alga coklat sebayak 1 kali sehari selama kurang dari 2 minggu mampu mengurangi kadar merkuri pada kulit tikus dengan aktivitas penyerapan sebesar 50\%.

\section{UCAPAN TERIMA KASIH}

Terima kasih kepada Kementerian Riset Teknologi Dan Pendidikan Tinggi Republik Indonesia yang telah memberikan bantuan dana dalam penelitian ini melalui Program Kreativitas Mahasiswa.

\section{DAFTAR PUSTAKA}

Anggadiredja, J.T., Achmad, Z., Heri, P., and Sri, I., 2011. Rumput Laut. Penebar Swadaya. Jakarta.

Ansel, H.C., 2005, Pengantar Bentuk Sediaan Farmasi. Edisi Keempat Penerbit Universitas Indonesia. Jakarta.

Armando, 2009. Memproduksi 15 Minyak Atsiri Berkualitas. Penebar swadaya, Jakarta.

Aulton, M. E., 2003. Pharmaceutics The Science of Dosage Form Design. ELBS Fonded by British Goverment.

Ben, H., and Nicolet, 1930, The Structure of Glutation. Journal of Biological Chemistry. 88: 389-393.

Chan, T.Y.K., 2011. Inorganic Mercury Poisoning Associated with Skin-lightening Cosmetic Products. Clinical Toxicology 49:886-891. 
Departemen Kesehatan Republik Indonesia. 1985. Formularium Kosmetika Indonesia. Departemen Kesehatan RI. Jakarta.

Ishak, R., and Abbas O, 2013. Penicillamine Revisited: Historic Overview and Review of the Clinical Uses and Cutaneous Adverse Effects. American Journal of Clinical Dermatology 14: 223-233.

Mah, V. and Jalilehvand, F., 2010. Glutathione Complex Formation With Mercury (II) In Aqueous Solution At Physiological pH. Chemical research in toxicology, 23, 1815-1823.

Mallkuci I. and Lazo P., 2014. Mercury Determination in Drug and Cosmetic Products. Current research 6(8).

Park Z.D., and Zheng W., 2012. Human Exposure And Health Effects Of Inorganic And Elemental Mercury. Journal Preventive Medicine and Public Health 344-352.

Patra, J.K., Rath, S.K., dan Jena, K., 2007. Evaluation of Antioxidant and Antimicrobial Activity of Seaweed (Sargassum sp.) Extract: A Study on Inhibition of Glutathione-S-Transferase. Journal of Biology 32: 119-125.

Piao, M.J., Eun, S.Y., Young, S.K., Hee, K.K., Junoh, K., Young, J.K., Hak, H.K., and Jin W.H., 2011. Antioxidant Effect of the Ethanol Extract from Flower of Camellia japonica via Scavenging of Reactive Oxygen Species and Induction of Antioxidant Enzymes. Molecular science 12:2618-2630.

Picquart M., Grajcar L., Baron M.H., and Abenzadeh Z., 1999. Vibrational Spectroscopic Study of Gluthathione Complexation in Aqueous Solutions. Biospectoscopy 5: 328-237.

Rafati, M.R., Rahimzadeh, Kazemi, S., and Moghadamnia, A.A., 2014. Current approaches of the management of mercury poisoning: need of the hour. DARU Journal of Pharmaceutical Science 22(46): 1-10.

Rowe, R. C., Sheskey, P. J. and Quinn, M. E., 2009. Handbook of Pharmaceutical Excipients. Pharmaceutical Press, London.

Scoville, W.L and Jenkins, G. L. 1957. Scoville's The Art of Compounding. Mc-Graw Hill Book Co. Inc, New York.

Silberg, I., Prutkin, L., and Leider, 2013. Electron Microscopic Studies of Transepidermal Absorption of Mercury. Enviromental Health 44(2): 7-14.

SNI 16-4399-1996. 1996. Sediaan Tabir Surya. BSN.

SNI 01-2346-2006. 2006. Petunjuk Pengujian Organoleptik dan atau Sensori. BSN.

Syamsuni, 2006. Farmasetika Dasar dan Hitungan Farmasi. Penerbit Buku Kedokteran EGC. Jakarta.

Voigt, R., 1984. Buku Pelajaran Teknologi Farmasi. diterjemahkan oleh Soewandi, S.N., Universitas Gajah Mada. Yogyakarta.

Wathoni, N., Rusdiana, T., and Hutagaol, R.Y. 2009. Formulasi Gel Antioksidan Ekstrak Rimpang Lengkuas (Alpinia galanga L. Willd) dengan Menggunakan Basis Aqupec 505 HV. Farmaka 7(1).

World Health Organization. 2014. Mercury In Skin Lightening Products. WHO. Geneva. 
Xiong, Z.Q., Mei, J.G., Yuan, X.G., Ju, C., Ying, Z., and Si, Z., 2008. Efficient Extraction of Intracellular Reduced Glutatione from Fermentation Broth of Saccharomyces cerevisiae by Ethanol. Bioresource Technology 1011-1014. 